\title{
ULUSLARARASI KURULUŞLAR AÇISINDAN KADININ GÜÇLENDIRILMESINE BAKIŞ
}

\author{
$\underline{\text { Neșe Yıldız }}$
}

${ }^{1}$ ORCID ID: https://orcid.org/0000-0002-4247-8163

\section{Öz}

"Kadınların güçlendirilmesi", günümüzde üzerinde çokça durulan, bilimsel çalışmalarda kullanılan, ulusal ve uluslararası politika belgelerinde ve sözleşmelerde kullanılan temel kavramlardan biri haline gelmiştir. Birleşmiş Milletler'den Avrupa Birliği'ne, Uluslararası Çalışma Teşkilatından, islam İşbirliği Teşkilatı'na kadar birçok uluslararası kurum ve kuruluş bu kavramı sıklıkla ve yaygın bir şekilde kullanmaktadır. Kadınların güçlendirilmesi, özellikle, kadınların ekonomik, sosyal, kültürel, siyasal hayatta desteklenmesi, daha görünür hale gelmesi ve etkin roller üstlenmesi gibi hedefler için kullanılmaktadır. Bu çerçevede, kadınların güçlendirilmesi, kadınların; fıtratının ve onurunun farkına varması, hayatının her döneminde kaliteli eğitim imkanlarına sahip olması; mesleki gelişim olanaklarının desteklenmesi; sağlık, güvenlik, huzur ve refahının sağlanması, iş dünyası- aile hayatı alanında dengenin kurulmasına yönelik tedbirler alınması, ulusal ve uluslararası düzeyde yasal haklarının ve sorumluluklarının farkına varması, dijital dönüşüm fırsatlarından yararlanması, ekonomik, sosyal, kültürel, siyasal olmak üzere toplumsal alanın her bir noktasında karar alma süreçlerine aktif katılımı için kendini hazırlaması ve hazır hissetmesi ile kadın üzerindeki tahakkümün ortadan kaldırılarak kadın-erkek birlikte ve güzel bir yaşam için gerekli bütün konuları içermektedir. Bu çalışmanın amacı, uluslararası düzenlemelerde kadının güçlendirilmesi konusunu inceleyerek, politika geliştirilmesine katkı sağlamaktır. Bu kapsamda, bu çalışmada, kadınların güçlendirilmesi alanında uluslararası düzenlemeler bağlamında Birleşmiş Milletler (BM), İslam Işsbirliği Teşkilatı (iiT), Uluslararası Çalışma Teşkilatı (ILO), Avrupa Konseyi (AK), Avrupa Birliği (AB), Grup 20 (G20)'nin yaklaşımları incelenerek kullanılan kavram, söylem ve politikaların kıyaslaması yapılacaktır

Anahtar Kelimeler: kadınların güçlendirilmesi, uluslararası kuruluşlar, uluslararası düzenlemeler

\section{Atıf için:}

Yıldız, N. (2020). Uluslararası kuruluşlar açısından kadının güçlendirilmesine bakış. HAKiş Uluslararası Emek ve Toplum Dergisi, 9 (25), 224-245.

\footnotetext{
${ }^{1}$ Dr. Öğr. Üyesi, Karabük Üniversitesi, İşletme Fakültesi, Uluslararası Ticaret Bölümü, Karabük/Türkiye E-posta: neseyildiz@karabuk.edu.tr
} 


\title{
AN OVERVIEW ON WOMEN'S EMPOWERMENT FROM THE PERSPECTIVE OF INTERNATIONAL ORGANIZATIONS
}

\begin{abstract}
"Women's empowerment" is turned out to be a concept which is recently very much focused on, widely used in scientific studies and national as well as international policy documents and conventions. Several international organizations varying from the United Nations to the European Union, from the International Labor Organization to the Organization of Islamic Cooperation are frequently and widely using this concept. This concept of "women's empowerment" is meant to support women in economic, social, cultural and political life, make them more visible and envisage for them effective roles. In this framework, women's empowerment includes the awareness of women's nature and dignity; having the quality of education in every period of her life; supporting of opportunities of women's professional developments; ensuring of women's health, peace and welfare; taking measures to establish the balance in the field of family and work life; realizing of their legal rights and responsibilities at national and international level; taking advantage of digital transformation opportunities; preparing and feeling ready for active participation of women in decision-making processes at every point of the social field including economic, social, cultural, political fields and a beautiful life together with man and women by eliminating the domination on women. The aim of this study is to contribute to policy development by examining the issue of women's empowerment in international arrangements. In this regard, concerning the women's empowerment in international arrangements, the concepts, terminologies, discourses and policies through the approaches of the United Nations (UN), Organization of Islamic Cooperation (OIC), International Labour Organization (ILO), The Council of Europe (COE), The European Union (EU), Group 20 (G20) will bw examined comparatively
\end{abstract}

Keywords: women's empowerment, international organisations, international arrangements 


\section{GíRIS}

"Kadınların güçlendirilmesi”, kavramı gerek ulusal gerek uluslararası alanda gerek gündelik hayatta gerek akademik çalışmalarda yaygın olarak kullanılmaktadır. Uluslararası kuruluşların da gündemlerinde, Sözleşmelerinde, politika belgelerinde ve kadına yönelik söylemlerinde en çok tercih edilen kavramlardan biridir. Bu kapsamda, Birleşmiş Milletler 'den Avrupa Birliği'ne, Uluslararası Çalışma Teşkilatından, İslam İşbirliği Teşkilatı'na kadar birçok uluslararası kurum ve kuruluş bu kavramı kullanmaktadır.

Kadınların güçlendirilmesi kavramının temel vurgusu, özellikle, kadınların ekonomik, sosyal, kültürel, siyasal hayatta desteklenmesi, daha görünür hale gelmesi, etkin roller üstlenmesi noktasındadır. Kadınların güçlendirilmesi, kadınların; fitratının ve onurunun farkına varması, hayatının her döneminde kaliteli eğitim imkanlarına sahip olması; mesleki gelişim olanaklarının desteklenmesi, sağlık, güvenlik, huzur ve refahının sağlanması, iş dünyasıaile hayatı alanında dengenin kurulmasına yönelik tedbirler alınmasıdır. Bu bağlamda kavram, kadınların ulusal ve uluslararası düzeyde yasal haklarının ve sorumluluklarının farkına varması, dijital dönüşüm fırsatlarından yararlanması, ekonomik, sosyal, kültürel, siyasal olmak üzere toplumsal alanın her bir noktasında karar alma süreçlerine aktif katılımı için kendini hazırlaması ve hazır hissetmesi ile kadın üzerindeki tahakkümün ortadan kaldırılarak birlikte ve güzel bir yaşam sağlanmasını içerecek şekilde gerekli bütün konuları içermektedir.

Kadının güçlendirilmesi çerçevesinde; fitrat, onur, liyakat, yetkinlik, işaile dengesinin sağlanması, evliliğin ve ailenin korunması, güvenli, insan onuruna yaraşır iş kavramları önümüzde temel değerler olarak bulunmaktadır. $\mathrm{Bu}$ çerçevede kadının güçlendirilmesi, kadının kendisinden beklenen temsil gücünü, etkin ve başarılı bir şekilde hayata geçirmesi anlamına gelmektedir.

Kadının güçlendirilmesi alanında kavram ve konu çeşitliliğine rağmen önümüzde esasında bir model bulunmamaktadır. Bu anlamda daha kapsamlı çalışma ve araştırmalara ihtiyaç bulunmaktadır.

$\mathrm{Bu}$ çalışmanın amacı, uluslararası düzenlemelerde kadının güçlendirilmesi konusunu inceleyerek, politika geliştirilmesine katkı sağlamaktır.

Bu kapsamda, bu çalışmada, kadınların güçlendirilmesi alanında uluslararası düzenlemeler bağlamında Birleșmiş Milletler (BM), İslam İşbirliği Teşkilatı (İIT), Uluslararası Çalışma Teşkilatı (ILO), Avrupa Konseyi (AK), Avrupa Birliği (AB), Grup 20 (G20)'nin yaklaşımları incelenerek, uluslararası kuruluşların kullandıkları kavram, söylem ve politikaların kıyaslaması yapılacaktır. 


\section{ULUSLARARASI DÜZENLEMELER ve KADINLARIN GÜÇLENDİRILMESİ}

II. Dünya Savaşı sonrası dönemde, günümüzde mevcut birçok uluslararası kuruluşunun temellerinin atılmıştır. Savaş koşullarını tecrübe eden uluslararası toplum, uluslararası kuruluşlar aracılığıyla, savaş koşullarının tekrar yaşanmaması, uluslararası alanda barışın, güvenliğin, iş birliğinin ve ekonomik kalkınmanın sağlanması adına çok sayıda adım atmıştır. Bu kapsamda temel insan haklarını güvenceye alan uluslararası sözleşmeler kabul edilmeye başlanmıştır. Kadınların hakları konusunda da birçok düzenleme gerçekleştirilmiştir. Kadınları ilgilendiren düzenlemeler, başlangıçta insan haklarıyla ilgili düzenlemeler içerisinde yer alırken, zamanla uluslararası kurumlar tarafından ayrı metinler olarak ele alınmıştır.

Günümüzde, uluslararası alanda faaliyet gösteren pek çok kuruluş "kadın" konusunda çalışmalar gerçekleştirmektedir. Bu kapsamda; Birleşmiş Milletler (BM), İslam İşbirliği Teşkilatı (IIIT), Uluslararası Çalışma Teşkilatı (ILO), Avrupa Konseyi (AK), Avrupa Birliği (AB) ve Grup 20 (G-20) kadın konusunda önemli çıtıtılar üreten hükümetler arası kuruluşlar olarak karşımıza çlkmaktadır.

Kadının güçlendirilmesi konusunda, hükümetler arası kuruluşlar dışında, ITUC (Uluslararası Sendikalar Konfederasyonu) ve ETUC (Avrupa Sendikalar Konfederasyonu) gibi uluslararası sendikal kuruluşlar ve STK'lar da bulunmaktadır. Ancak bu çalışmada uluslararası kuruluşlar ve STK'lar ele alınmayacaktır. Uluslararası kuruluşlar, kadınlara yönelik konuları; Antlaşmalar, Sözleşmeler, Bildirgeler, Tavsiye Kararları, Strateji Belgeleri, Eylem Planları gibi mekanizmalar geliştirerek ele almakta ve yaklaşımlarını ortaya koyarak sürece etki etmeye çalışmaktadırlar. Bu bölümde, bu belgeler ve yaklaşımlar değerlendirilecektir.

\section{BİRLEŞMIŞ MILLLETLER ve KADINLARIN GÜÇLENDİRÍLMESİ}

Birleşmiş Milletler (BM), kuruluşundan günümüze, kadınlara yönelik birçok düzenlemeye yer vermiştir. Bu kapsamda yer alan temel BM düzenlemeleri; Kadına Karşı Her Türlü Ayrımcılığın Önlenmesi Sözleşmesi (CEDAW), Kadına Karşı Şiddetin Önlenmesine Dair Birleşmiş Milletler Bildirgesi, Pekin Deklarasyonu ve Eylem Planı, Binyıl (Milenyum) Kalkınma Hedefleri, Kadınların Güçlendirilmesi Prensipleri ile 2030 Sürdürülebilir Kalkınma Amaçları adlı çalışmalar șeklindedir.

\section{BM Kadına Karşı Her Türlü Ayrımcılığın Önlenmesi Sözleşmesi (CEDAW)}

BM'nin kuruluşuyla beraber birçok uluslararası düzenleme yavaş yavaş ortaya konulmaya başlanmıștır. Bu düzenlemelerde, kadın hakları veya kadınların güçlendirilmesi ile ilgili münhasır düzenlemeler olmamakla beraber, 
yasalar önünde haklarda eşitlik ilkesi çerçevesinde hükümler göze çarpmaktadır. Örneğin, 1949 yılında kabul edilen İnsan Hakları Evrensel Bildirgesi cinsiyet dahil hiçbir ayrımcılığa maruz kalınamayacağını düzenlemektedir. 1966'da imzalanıp, 1976'da yürürlüğe giren Uluslararası Medeni ve Siyasal Haklar Sözleşmesi ile Uluslararası Ekonomik, Sosyal ve Kültürel Haklar Sözleşmesi gibi sözleşmelerde de kadınlarla ilgili olarak, özellikle, kanun önünde eşitlik, ayrımcllık yasağı, eşit işe eşit ücret, anneliğin korunması gibi konulara yer vermiştir.

BM tarafından 1979 yllında kabul edilip 1981 yılında yürürlüğe giren CEDAW ise başlı başına kadınlarla ilgili düzenlemeye yer veren, kadınlara yönelik ayrımcllğı ortadan kaldırmayı hedefleyen bir sözleşme olarak öne çımaktadır. CEDAW, bu amaçla, somut adımlar ortaya koymaktadır. 2020 yılı itibariyle 189 ülke tarafından onaylanmıștır.

CEDAW, politik, sosyal, ekonomik ve kültürel alanlar başta olmak üzere bütün alanlarda, eğitimde, haklardan yararlanmada, istihdamda, hamilelik öncesi ve sonrası süreçte, kanun önünde, evlilik ve aile ilişkilerinde, kırsal yaşamda her türlü ayrımcllı̆̆ın önlenmesine dair hükümler içermektedir.

Sözleşme gündemindeki gelişmeleri izlemek üzere bir komite kurulması düzenlenmiştir. Sözleşmeyi kabul eden ülkeler sözleşme hükümlerini yerine getirmek amacıyla; kadınlara yönelik ayrımcılığı önleyen bir politikayı iç hukuklarında uygulamak, ulusal mevzuatını sözleşmeyle uyumlu hale getirmek ve CEDAW Komitesi'ne düzenli olarak rapor hazırlamak zorundadır (Kadınlara Karşı Her Türlü Ayrımcılığın Önlenmesi Uluslararası Sözleşmesi).

CEDAW Komitesi tarafından, 1999 yılında CEDAW İhtiyari Protokol'ü kabul edilmiştir. Bu protokol ile taraf devletlerin CEDAW'ı ihlal etmeleri durumunda, kişilere ve gruplara CEDAW Komitesine başvuru hakkı tanınmıştır.

\section{BM Kadına Karşı Şiddetin Önlenmesine Dair Bildirgesi}

Kadınlara Yönelik Şiddetin Ortadan Kaldırılmasına Dair Bildirge, 1993 yllında kabul edilmiştir. Bu bildirge, uluslararası hukuk açısından kadına yönelik şiddetin önlenmesi noktasında ilk önemli belge niteliğini taşımaktadır.

Bu bildirge, Kadınlara Karşı Her Türlü Ayrımcılığın Önlenmesi Sözleşmesi'nin (CEDAW) etkin olarak uygulanarak, kadınlara yönelik şiddetin önlenmesine katkıda bulunmayı hedeflemektedir.

Bildirgede, kadınlara yönelik şiddet kavramının tanımı, şiddetin içeriğinde yer alan unsurlar; kadın hakları ve özgürlükleri, şiddetin önlenmesi, failin cezalandırılması ve şiddete uğrayanın korunması konusunda devletlere düşen hukuksal, eğitimsel ve mali sorumluluklar ve görevler düzenlenmektedir. Aynı zamanda sivil toplum kuruluşlarıyla iş birlikleri teşvik edilmektedir (Kadınlara Yönelik Şiddetin Ortadan Kaldırılmasına Dair Bildirge). 


\section{BM Pekin Deklarasyonu ve Eylem Planı}

1995 yılında BM tarafından düzenlenen Pekin Kadın Konferansında, Pekin Deklarasyonu ve Eylem Planı kabul edilmiştir.

Pekin Deklarasyonu ve Eylem Planında, uluslararası topluluk ve hükümet dışı kuruluşlarla özel sektörün dahil olduğu sivil toplum bazı konularla ilgili, stratejik eylemler yapmaya çağrılmaktadır. Bu hususları; kadınların sırtında bulunan devamlı ve artan yoksulluk yükü; eğitim ve öğretimdeki eșitsizlikler ve yetersizlikler, bunlara ulaşmadaki eşitsizlik; sağlık ve bağlantılı hizmetlerdeki eşitsizlikler ve yetersizlikler, bunlara ulaşmadaki eşitsizlik; kadına yönelik şiddet; silahlı veya diğer türden çatışmaların, yabancı işgali altında yaşayanlar dahil, kadınlar üzerindeki etkileri; ekonomik yapılarda ve politikalarda, üretime yönelik her tür faaliyette ve kaynaklara ulaşmada eşitsizlik; yetki ve karar almanın bütün düzeylerde paylaşılmasında kadınla erkek arasındaki eşitsizlik; kadının ilerlemesini sağlayacak bütün düzeylerdeki mekanizmaların yetersizliği; kadının insan haklarına saygı eksikliği, bu hakların yaygınlaştırılması ve korunmasında yetersizlik; kadının klişeleştirilmesi ve özellikle medya olmak üzere kadının bütün iletişim sistemlerine katılımında ve erişiminde eşitsizlik; doğal kaynakların yönetiminde ve çevrenin korunmasında toplumsal cinsiyete dayalı eşitsizlikler; kız çocuklarına karşı sürekli ayrımcllık ve kız çocuklarının haklarının ihlali şeklinde sıralayabiliriz (Dördüncü Kadın Dünya Konferansı Sonuçları: Pekin Deklarasyonu ve Eylem Planı, 1995, s.14,15).

\section{BM Binyıl (Milenyum) Kalkınma Hedefleri}

Birleşmiş Milletler Genel Kurulu 2000 yılında, 2015 yılına kadar gerçekleşmesi hedeflenen 8 hedef belirlemiştir. Bu hedefler Binyıl Kalkınma Hedefleri olarak adlandırılmaktadır. Binyıl Kalkınma Hedefleri aşırı yoksulluk ve açlığın ortadan kaldırılması, evrensel ilköğretimin gerçekleştirilmesi, kadın-erkek eşitliğinin sağlanması ve kadınların konumunu güçlendirilmesi, çocuk ölümlerinin azaltılması, anne sağlığının iyileştirilmesi, HIV/AIDS, sıtma ve öteki hastalıklarla mücadele edilmesi, çevresel sürdürülebilirliğin sağlanması, kalkınma için küresel bir ortaklık geliştirilmesi başlıklarına yer vererek 8 konuyu ele almaktadır.

Kadın-erkek eşitliğinin sağlanması ve kadınların konumunun güçlendirilmesi hedefi kapsamında, kadınların toplumsal hayattaki pozisyonlarının güçlendirilmesi ile İlköğretim ve orta öğretimde kız-erkek öğrenci eşitsizliğinin her düzeyde giderilmesi hedeflenmektedir (https://www.tr.undp.org/content/turkey/tr/home/mdgoverview/millennium-development-goals.html).

2015 yılına gelindiği zaman BM tarafından Milenyum hedeflerine ilişkin bir değerlendirme yapılmıştır. BM değerlendirme raporunda; 2000 yılıyla karşılaştırıldığında daha fazla kız çocuğunun okul hayatına katıldığı, geliş- 
mekte olan bölgelerin tamamında ilköğretimde, ortaöğretimde ve yükseköğretimde kız öğrencilerin lehine iyileşmelerin yaşandığı dile getirilmektedir. İşgücü piyasasında da kadınlar lehine daha olumlu düzenlemeler olmakla beraber, genel olarak kadınların dezavantajlı pozisyonunu sürdürdükleri, yoksulluğa daha fazla maruz kaldıkları, kadınların karar verme mekanizmalarında daha fazla temsil edildiği özetle, küresel düzeyde, cinsiyet eşitliğinin sağlanması alanında olumlu gelişmeler yaşanmasına rağmen, önemli sorunların varlığını sürdürdüğü ve ilave tedbirlerin alınması gerektiği vurgulanmıştır (UN, 2015, s.5-8).

BM'nin ortaya koyduğu Milenyum Kalkınma Hedeflerinin ardından, iş dünyasının bu hedeflere katkı sağlaması amacıyla Küresel İlkeler Sözleşmesi (Global Compact) kabul edilmiştir. Küresel İlkeler Sözleșmesi kapsamında insan hakları, çalışma standartları, çevre ve yolsuzlukla mücadele kapsamında 10 ilkeye yer verilmiştir. Çalışma standartları alanında belirlenen ilkelerden biri de işe alım ve işe yerleştirmede ayrımcllı̆̆a son verilmesidir.

\section{BM Kadınların Güçlendirilmesi Prensipleri (WEP’s)}

Kadınların Güçlenmesi Prensipleri (Women's Empowerment Principles WEPs), Birleşmiş Milletler Toplumsal Cinsiyet Eşitliği ve Kadının Güçlenmesi Birimi olan BM Kadın (UN Women) ve Global Compact (Küresel İlkeler Sözleșmesi) girişimi tarafından geliştirilmiștir. 7 maddeden oluşan hükümler, 2010 yılında yürürlüğe girmiştir.

Kadınların Güçlenmesi Prensipleri; işyerlerinde, piyasalarda ve toplum genelinde toplumsal cinsiyet eşitliğinin sağlanması amacıyla şirketlere aşağıda yer alan 7 öneri sunmaktadır:

- İş yaşamında cinsiyet eşitliği için üst düzeyde liderlik ortaya konulması,

- Kadın ve erkek tüm çalışanlara işyerinde adil davranılması, insan hakları ve ayrımcılık yasağı ilkelerine saygı gösterilmesi ve destek verilmesi,

- Kadın ve erkek tüm bireylerin sağlık, güvenlik ve refahlarının sağlanması,

- Kadınların her türlü eğitim, öğretim ve mesleki gelişim konusunda teşvik edilmesi,

- İşyerinde; girişim, iş geliştirme, tedarik zinciri ve pazarlama süreçlerine ilişkin uygulamaların kadınların güçlenmesine yarayacak şekilde yürütülmesini sağlanması,

- Toplumsal inisiyatifler ve savunuculuk aracllığıyla eşitliğin teşvik edilmesi,

- Cinsiyet eşitliğine ilişkin ilerlemenin ölçülmesi ve sonuçlarının kamuoyu ile paylaşılmasıdır (http://www.weprinciples.org/).

İş dünyası kuruluşları, Kadınların Güçlenmesi Prensiplerini imzalayarak, toplumsal cinsiyet eşitliğini ilerletecek şirket politikaları oluşturma ve uygulama konularında taahhütte bulunmaktadır. 
Kadınların Güçlendirilmesi Prensipleri- WEPs 28 Temmuz 2020 itibariyle dünya genelinde, 3373 şirket tarafından imzalanmıştır. Türkiye'de WEPs'i imzalayan şirket sayısı 320'dir. Türkiye, bu prensipleri imzalayan şirket sayısı bakımından 400 imzacısı bulunan Brezilya'nın ardından 2. Sırada yer almaktadır. Türkiye'yi 254 imzacı şirket ile Japonya 3. Sırada takip etmektedir (https://www.weps.org/companies). Türkiye'deki imzacı şirketlerin sayısı, kadın konusundaki duyarlılığın bir göstergesi olarak övgüye değer bir durum ortaya çıkarmaktadır.

\section{BM 2030 Sürdürülebilir Kalkınma Amaçları}

2015 Milenyum Kalkınma Hedefleri'nin değerlendirilerek, hedeflere ulaşmada ilerlemeler olmakla beraber yetersizliklerin tespit edilmesi üzerine, BM tarafından 2030 Sürdürülebilir Kalkınma Amaçları oluşturulmuştur. Bu kapsamda yer alan 17 amaç şu şekildedir: yoksulluğa son verilmesi, açlı̆̆ın yok edilmesi, sağlık ve refah, kaliteli eğitim, cinsiyet eşitliği, sağlıklı suya erişim, erişilebilir temiz enerji, istihdam ve ekonomik büyüme, sanayi, yenilikçilik ve altyapı, eşitsizliklerin azaltılması, sürdürülebilir şehirler ve topluluklar, bilinçli üretim-tüketim, iklim değişikliğiyle mücadele, sudaki yaşam, karadaki yaşam, sulh ve adalet ile uygulama araçları şeklindedir.

Kalkınma Amaçlarında yer alan Amaç 5, cinsiyet eşitliği başlığını taşımakta, cinsiyet eşitliğini sağlamayı, tüm kadınları ve kız çocuklarını güçlendirmeyi amaçlamaktadır. Amaç 5 altında ele alınan konular şu şekildedir:

- Kadınlara ve kız çocuklarına yönelik her türlü ayrımcılığın her yerde sonlandırılması,

- Kamu alanları ve özel alanlarda, tüm kadınlara ve kız çocuklarına yönelik, kadın ticareti, cinsel ve her türlü istismarı da kapsayan şiddetin her türünün yok edilmesi,

- Çocuk evliliği, erken yaşta ve zorla evlendirilme ile kadın sünneti gibi tüm zararlı uygulamaların yok edilmesi,

- Ulusal şartlara uygun şekilde kamu hizmetlerinin, altyapının ve sosyal koruma politikalarının sağlanması ile hane halkı ve aile içerisinde sorumlulukların paylaşımının teşvik edilmesi yollarıyla ücretsiz bakım ve ev işlerinin tanınması ve değer atfedilmesi,

- Kadınların siyasi, ekonomik ve sosyal hayatta, karar alma süreçlerinin her seviyesinde tam ve etkili katılımı ile liderlik edebilmeleri için eşit fırsatlar sağlanması,

- Uluslararası Nüfus ve Kalkınma Konferansı Eylem Programı, Pekin Eylem Platformu ve bunların gözden geçirme konferanslarının sonuç dokümanları çerçevesinde mutabık kalınan şekilde cinsel ve üreme sağlığına ve üreme haklarına evrensel erişimin sağlanması, 
- Kadınların ulusal yasalarla uyumlu olacak şekilde toprak ve diğer mülk türlerine sahip olma ve hükmetme, mali hizmetler, miras ve doğal kaynaklara erişimlerinin sağlanmasını da kapsayacak șekilde ekonomik kaynaklar konusunda eşit haklara sahip olmaları için reformlar yapılması

- Kadınların güçlendirilmesini destekleyen teknolojilerin, özellikle bilgi ve iletişim teknolojilerinin kullanımının artırılması

- Kız çocuklarının her seviyede güçlendirilmesi için sağlam politikalar ile uygulanabilir mevzuatların kabul edilmesi ve güçlendirilmesidir (http://www.surdurulebilirkalkinma.gov.tr/hedefler/cinsiyet-esitliginisaglamak/).

BM tarafından geliştirilen 2030 Sürdürülebilir Kalkınma Amaçları, küresel alanda en çok referans alınan çalışmalardan birini oluşturmaktadır. Birçok uluslararası kuruluş Kalkınma Amaçlarında yer alan konuları, politikalarının merkezine alarak, gündem maddelerine ilişkin kendi katkısını ortaya koymaya çalışmaktadır.

\section{İSLAM IŞBíRLIĞ́i TEŞKILATI (IIIT) ve KADININ GÜÇLENDİRILMESİ}

İslam İşbirliği Teşkilatı (İIT), kadınların güçlendirilmesi alanında, gerek düzenli olarak düzenlediği Bakanlar düzeyindeki toplantılarla, gerek eylem programları ve gerekse geliştirdiği strateji belgeleriyle çalışmalar yürütmektedir. İ̇T'nin çalışmaları bağlamında İ̇T 2025 Eylem Programı ile İ̇T Evlilik ve Aile Kurumunun Güçlendirilmesi Stratejisi konuları ele alınacaktır.

\section{İiT 2025 Eylem Programı}

İslam Dünyasının hak ve çıkarlarını korumak ve üye devletlerarasında işbirliği ve dayanışmayı güçlendirmek üzere 1969 yılında İslam Kalkınma Örgütü kurulmuştur. 2011 yılında ise Örgütün adı, İslam İşbirliği Teșkilatı (iïT) olarak değişmiștir.

İंT, kadınları ilgilendiren konularla ilgili olarak 2005 'te 10 yıllık hazırladığı Eylem programının ardından ikinci eylem programı da 2016- 2025 yıllarını kapsayacak şekilde hazırlamıştır. Programda öne çıkan vurgular, kadınların ilerletilmesi ve güçlendirilmesi, aile refahının ve sosyal güvenliğin sağlanması, çocuk ve anne sağlığının korunması, yaşlıların korunması, kadınların iyi sağlık koşullarına sahip olması, kadınların işgücüne katılım oranının artırılması, kadınlara ait işletmelerin desteklenmesi şeklindedir. Eylem programında kadınlara yönelik tedbirlerin, aile kavramının ve aile bireylerinin etrafında şekillendiğini vurgulamak gerekir (The Oic - 2025 Programme of Action). 


\section{İiT Evlilik ve Aile Kurumunun Güçlendirilmesi Stratejisi}

Aile ve evlilik kavramı üzerine birçok tartışmaların yürütüldüğü, ailenin birçok dışsal faktörden etkilendiği günümüzde İslam İşbirliği Teşkilatı, aile ve evlilik kavramına sahip çlkarak, politikalarının merkezinde aile ve evlilik kurumunun olduğu vurgusunu yapmaktadır. 2020 yılında hazırlanan bu belgede, öncelikle kadın ve erkek arasındaki evliliğin desteklenmesi ve sağlıklı ailenin temel unsurları üzerinde durulmaktadır.

Ailenin ve evliliğin güçlendirilmesinde ailede İslami değerlerin ve Müslüman kimliğin güçlendirilmesinin altı çizilmekte, iş ve aile dengesinin sağlanması, kadın ve erkek arasında sorumlulukların paylaşıldığı ailenin inşası üzerinde durulmaktadır (OIC Strategy for the Empowerment of the Marriage \& Family Institution 2020-2025).

\section{ULUSLARARASI ÇALIŞMA ÖRGÜTÜ (ILO) ve KADININ GÜÇLENDİRIL- MESI}

Uluslararası Çalışma Örgütü (ILO), kadınların güçlendirilmesine yönelik Sözleşme ve Tavsiye kararları, Eylem Planları ve Bildirgeler gibi düzenleme ve politika belgeleriyle katkı sağlamaktadır.

Kurulduğu tarihten itibaren çalışma hayatında kadınların işgücüne katıllmının artırılması için çalışmalar ortaya koyan ILO, bu alanda uluslararası norm ve standartların oluşmasına önemli katkılar sağlamakta, Sözleşme ve Tavsiye Kararlarının yanı sıra gerek kendi içinde gerekse uluslararası kuruluşlarla iş birliğini sürdürerek çalışma hayatında kadınları güçlendirmek için birçok adım atmaktadır. ILO, üye ülkelerde kadınları güçlendirmek amacıyla sosyal taraflarla projeler geliştirmektedir. Ayrıca 2009 yllından itibaren, kendi bünyesinde Eylem Planları ortaya koyarak konuyu sürekli gündeminde tutmaktadır.

ILO, temel insan hakları ve kadın istihdamını doğrudan veya dolaylı olarak etkileyen birçok Sözleşme ve Tavsiye Kararı kabul etmiştir. ILO'nun, ayrımcılığın ortadan kaldırılması, iş ve aile sorumluluğu, anneliğin korunması ve kadın sağlığı, gece çalışması ve yeraltı işleri ile işyerinde kadınların çalışmasının düzenlenmesi konularında sözleşme ve tavsiye kararları bulunmaktadır. Bu beş başlıkta, kadınları doğrudan ilgilendiren 11 Sözleşme, 9 Tavsiye Kararı ortaya koymuştur. Bu konularla dolaylı olarak ise, 12 Sözleşme 10 Tavsiye kararı almıştır. ILO, bu çalışmalarıyla, özel olarak kadın istihdamı alanında asgari düzenlemeler gerçekleștirmekte, kadın istihdamının artırılmasını hedeflemektedir.

2019 yılında ILO'nun 100. Kuruluş yıldönümünde kabul edilen 190 Sayılı Şiddet ve Taciz Sözleşmesi de bütün çalışanlara yönelik olarak işyerinde şiddetin ve tacizin önlenmesini hedeflemektedir. Kadınlar şiddete ve tacize daha çok muhatap olduğu için bu Sözleşme özellikle kadınları yakından ilgilendirmektedir. 
ILO'nu kadın konusunda yaptığı vurgular, kullandığı temel kavramlar şunlardır: cinsiyet eşitliği, ayrımcılı̆̆ın ortadan kaldırılması, eşit ücret, firsat ve muamele eşitliği, ekonomik ilerlemenin sonuçlarının eşit dağılımı, ayrımcılık yasağı, ayrımcılığın bütün şekillerinin ortadan kaldırılması, işgücü piyasasına hazırlanmada, giriște, katılmada ya da ekonomik aktivitelerde ilerlemede aile sorumluluklarının yerine getirilmesinin engel oluşturmaması, firsat ve muamele eşitliği, analığın korunması ve kadın sağlığı, eğitime ve mesleki eğitime kadınların erişimi, işyeri ortamının kadın çalışanlara da uygun şekilde dizayn edilmesi, kırsal alanlardaki kadınların istihdamının sağlanması, işletmelerindeki üst düzey pozisyonlara terfide eşit erişim firsatları, evlilik durumu, yaş ve aile sorumlulukları noktasında kadınların ayrımcılığa maruz kalmaması, hamilelik ve doğum durumlarında kadınların haklarının korunması, evlatlık çocuk edinen ailelerin çocuk bakımı için izin hakları, sosyal güvenlik ve emeklilik sistemlerinde engellerin kaldırılması, çalışanların, işe alınması, yerleștirilmesi, eğitimi ve ilerletilmesinde nitelik, beceri ve deneyim kriterlerine riayet, istihdam ve mesleki düzeyde ayrımcılığın yok edilmesi (Yıldız, 2017, s.67).

\section{AVRUPA KONSEYİ ve KADININ GÜÇLENDİRILLMESI}

Avrupa Konseyi kadınların güçlendirilmesine yönelik çalışmalar ortaya koymaktadır. Bu çalışmaların en önemlisi Kadına Yönelik Şiddet ve Aile İçi Şiddetin Önlenmesi ve Bunlarla Mücadeleye İlişkin Avrupa Konseyi Sözleşmesi (İstanbul Sözleşmesi)'dir.

\section{Kadına Yönelik Şiddet ve Aile İçi Şiddetin Önlenmesi ve Bunlarla Mücadeleye İlişkin Avrupa Konseyi Sözleşmesi (İstanbul Sözleşmesi)}

1949 yılında kurulan Avrupa Konseyi, amacını; insan hakları, hukukun üstünlüğü ve demokrasi ilkelerini korumak ve güçlendirmek olarak ortaya koymaktadır. Kuruluşundan itibaren amaçlarına hizmet etmek üzere 223 Antlaşma imzalamıştır. Bu çerçevede, birçok sözleşmede (Avrupa İnsan Hakları Bildirgesi, Avrupa Sosyal Şartı, Gözden Geçirilmiş Avrupa Sosyal Şartı vs) kadınlara yönelik düzenlemelere yer vermiştir. Bu sözleșmelerde, ayrımcılık yasağı, fursat eşitliği ve eşit muamele görme hakkı, çalışan kadınların özel korunma hakkına sahip olması ve anaların korunması hakkı gibi konular yer bulmuştur.

Avrupa Konseyi- İstanbul Sözleșmesi ise doğrudan şiddetin önlenmesini içeren sözleşme olması itibariyle dikkat çekmektedir. İstanbul Sözleşmesi, Avrupa Konseyi'nin ortaya koyduğu, kadına yönelik șiddet ve bununla mücadeleyi gündemine alan kapsamlı uluslararası sözleşmelerden biridir. Kadına karşı şiddet ve aile içi şiddet konusunda uluslararası alanda yaptırım gücü olan ilk sözleşme niteliği taşımaktadır. Sözleşme ile CEDAW'ın güçlenmesi de hedeflenmiştir. 
İstanbul Sözleşmesi, 11 Mayıs 2011 tarihinde imzaya açılmış, Avrupa Konseyi üyesi olan Azerbaycan ve Rusya dışında 45 üye ülke tarafından imzalanmıştır. İmzacı ülkelerin 33'ü tarafından sözleşmenin onaylanması da gerçekleşmiştir. Avrupa Birliği de uluslararası kuruluş olarak sözleşmeyi imzalamıștır. Sözleşme, 2014 yılında yürürlüğe girmiștir.

Türkiye, imzaya açma töreninde 13 ülkenin imzaladığı Sözleşme'ye imza koyan ve onaylayan ilk ülke olmuştur. İstanbul Sözleşmesinin amacı sözleşmede şu şekilde ifade edilmektedir:

- Kadınları her türlü şiddetten korumak, kadına yönelik şiddet ve aile içi şiddetle mücadele etmek, şiddeti önlemek ve kovuşturmak;

- Kadına yönelik her türlü ayrımcılı̆̆ın ortadan kaldırılmasına katkıda bulunmak ve kadınları güçlendirerek kadın erkek eşitliğini teşvik etmek;

- Kadına yönelik şiddet ve aile içi şiddet mağdurlarının korunması ve mağdurlara yardım edilmesi için kapsamlı çerçeve, politikalar ve önlemler geliştirmek;

- Kadına yönelik şiddeti ve aile içi şiddeti ortadan kaldırmak amacıyla uluslararası iş birliğini geliştirmek;

- Kadına yönelik şiddet ve aile içi şiddeti ortadan kaldırmaya yönelik bütüncül bir yaklaşım benimsemek amacıyla etkili iş birliğini sağlamaya yönelik kuruluşlar ve yasa koyuculara destek ve yardım sunmaktır.

Sözleşmede; kadına yönelik şiddet, aile içi şiddet, toplumsal cinsiyet, toplumsal cinsiyete dayalı şiddet, mağdur ve kadın kavramları tanımlanmış, cinsel yönelim kavramı kullanılmış, temel haklar, eşitlik ve ayrımcılık yapmama, devlet yükümlülükleri ve gereken özeni gösterme, toplumsal cinsiyete duyarlı politikalardan bahsedilmiștir.

Sözleşme ile kadına karşı şiddetle mücadelede; şiddeti önleme, şiddet mağdurunu koruma, şiddet uygulayanı soruşturma, kadına karşı şiddetin sonlandırılmasına yönelik politikalarını izleme mekanizmalarına yer verilmektedir.

Sözleşme kapsamında şiddetin önlenmesinde oldukça ayrıntılı düzenlemelerin yapıldığı görülmektedir. Bu kapsamda; mağdurlarla yakın etkileşim halinde olan uzmanların eğitimi, farkındalığı artırma kampanyalarına yer verilmesi, sivil toplumla etkin işbirliğinin kurulması, önleyici müdahale, tedavi programları, cinsiyet eşitsizliğiyle mücadelede ve karşılıklı saygının oluşturulmasında özel sektör ve medya desteğinin alınması, psikolojik ve hukuki destek hizmetleri, sığınakların kurulması, acil yardım hatlarının açılması, çocuk tanıklar için koruma, bedensel zarar görenlere tazminat, adli yardım hizmetleri gibi konular detaylandırılmıştır (Kadınlara Yönelik Şiddet ve Aile İçi Şiddetin Önlenmesi ve Bunlarla Mücadeleye İlişkin Avrupa Konseyi Sözleşmesi).

İstanbul Sözleşmesine yönelik önemli eleştiriler ve tartışmalar yapılmaktadır. Bu eleştirilerden biri sözleşmenin kullandığı kavramların Türkiye'nin aile yapısı, kültürü, inanç ve değerleriyle çatışması noktasındadır. İkinci tartışma ve eleştiri ise Sözleșmenin önerdiği çözüm yöntemlerinin uygunluğu 
noktasındadır. Üçüncü tartışma ve eleştiri noktası ise, Sözleşmeyi iç hukuka uyarlayan 6284 Sayılı Ailenin Korunması ve Kadına Yönelik Şiddetin Önlenmesi Hakkındaki Kanunun uç ve radikal yaklaşıma sahip olması noktasındadir.

\section{AVRUPA BİRLİĞí (AB) ve KADININ GÜÇLENDİRÍLMESí}

Avrupa Birliği (AB), kadınların güçlendirilmesi konusuyla ilgili olarak birçok düzenleme gerçekleştirmiştir.

AB'nin temellerinin atılmasıyla "kadın" konusu $A B$ mevzuatına dahil olmuş, $A B$ Antlaşmalarında, $A B$ Direktiflerinde ve birçok çalışmada bu konu ele alınmıștır. Konuyla ilgili $\mathrm{AB}$ Komisyonu ve Parlamentosu başta olmak üzere bünyesinde birimler olușturmuştur. 1975 yllından itibaren toplam 16 adet Direktif çıkarılmış, Direktiflerde, eşit ücret, eşit muamele, sosyal güvenlikte muamele eşitliği, hamilelik ve analık süresince korunma, ebeveyn izni konularına yer verilmiştir.

Avrupa Birliği'nin, kadınların güçlendirilmesi alanında kullandığı temel kavramlar şu şekildedir: cinsiyet eşitliği, eșit işe eşit ücret, eşit firsatlar, cinsiyete dayalı ayrımcılık yasağı, kadın ve erkek çalışanların aile ve meslek yaşamlarını uzlaştırabilmesi, cinsel tercih temelinde yapılan ayrımcılıkla mücadele, eşitliğin, istihdam, çalışma ve ücret dahil olmak üzere bütün alanlarda sağlanması, sosyal dışlanma ve ayrımcılık ile mücadele, sosyal güvenlik alanında kadın ve erkeğe muamele eşitliği, hamilelik ve analık süresince korunma, istihdamda ve meslekte eşit muamele, kız çocuklarının ve kadınların güçlendirilmesi konusunda liderliğe önem verilmesi, cinsiyet politikası vaatlerinin gerçekleşmesi için yeterli kaynak ayrılması, kız çocuklarının ve kadınların fiziksel ve psikolojik bütünlüğunnün sağlanması, kız çocuklarının ve kadınların sosyal-ekonomik haklarının korunması ve güçlendirilmesi, kız çocuklarının ve kadınların seslerinin ve katılımlarının güçlendirilmesi, kız çocuklara ve kadınlara karşı şiddetin her şekliyle mücadele edilmesi, kız çocuklarının ve kadınların kaçakçılığına/ticarileștirilmesine (trafficking) yönelik her türlü sömürü yönteminin ortadan kaldırılmasıdır. Ayrıca, her yaştaki kadına ve erkeğe yönelik cinsel ve cinsiyet temelli şiddete karşı koruma sağlanması, kız çocuklarının ve kadınların kaliteli hizmet veren fiziksel ve zihinsel bakım hizmetlerine eşit erișimi, her bireyin kendi cinsiyeti, cinsel ve üreme sağlığı hakkında ayrımcllıktan, baskıdan ve şiddetten uzak bir şekilde özgür ve sorumlu olarak karar vermesi, kız çocuklarının ve kadınların yaşam döngüsü boyunca sağlıklı beslenme imkanlarına kavușturulması, kız çocuklarının ve kadınların her seviyedeki kaliteli eğitime, mesleki eğitime ve öğretime ayrımcılıktan uzak bir şekilde erişiminin sağlanması, her yaștaki kadının insan onuruna saygin iş olanaklarına erișiminin sağlanması, üretken kaynaklara kadınların eşit erişiminin sağlanması, kız çocuklarının ve kadınların temiz su, enerji, ulaşım altyapısına eşit erişiminin sağlanması, politika ve yönetişim süreçlerine katılımda kadınların eşit haklara ve yeterliliğe sahip olması, 
cinsiyet eşitliği ile kız çocuklarının ve kadınların güçlendirilmesi alanında çalışan kadın örgütlerine, STK'lara ve insan hakları savunucularına özgürce çalışma ve kanunla korunma hakkı sağlanması, ayrımcı sosyal normlar ve kalıplarla mücadele edilmesi ve değiştirilmesi, kadınların, iklim ve çevresel konularda politika yapım sürecine etki etmesi ve katılım sağlanmasında eşit haklara sahip olması şeklinde sayısız ayrıntılı konulardan oluşmaktadır (Yıldiz, 2017, s.70,71).

\section{G20 (GRUP 20) ve KADININ GÜÇLENDİRILMESİ}

G20, kadının güçlendirilmesi alanında gerek bünyesinde oluşturduğu W20 (Kadın 20), gerekse G20 Zirvelerinde yayınlanan Sonuç Bildirgeleriyle gündem oluşturmaktadır.

1999 yılında küresel ekonomik meseleleri, üye ülkelerin Finans Bakanları ve Merkez Bankası Başkanlarıyla istişare etmek üzere kurulan, küresel finansal kriz nedeniyle 2008 yılından sonra ise Liderler seviyesinde Zirveler düzenlemeye başlayan G20, Zirve sonrası Bildiriler yayınlayarak önceliklerini, olaylara bakış akışını ve politika yaklaşımını ortaya koymaktadır. G20 Liderler Zirvesi sonrası yayınlanan "Liderler Bildirgeleri"nde "kadın" konusuyla ilgili değerlendirmelere 2012 Meksika-Los-Cabos Zirvesiyle beraber yer verilmeye başlandığı görülmektedir.

\section{G20- Kadın 20 (W20)'nin Kurulması}

2015 yılında Türkiye Dönem Başkanlığındaki G20'nin çalışmalarından en önemlisi G20 çatısı altında bulunan W20 (Kadın 20) açılım-diyalog grubunun kurulmasıdır.

Daha önce G20 kapsamında B20 (İş Dünyası 20), L20 (Emek 20), C20 (Sivil 20), T20 (Düşünce 20), Y20 (Gençlik 20) adı altında diyalog grupları kurulmuştur. W20'nin kurulması ile kadın konularına ilişkin konular, üye ülkelerden gelen ilgili temsilcilerin katılımıyla G20 çatısı altında ele alınmaya başlanmıştır. Böylece, G20 bünyesinde kadına ilişkin konular daha detaylı olarak ele alınmaya başlanmıștır.

\section{G20- 2019 Japonya Liderler Zirvesi Sonuç Bildirgesi}

2019 yılında Japonya Osaka'da düzenlenen Liderler Zirvesi yayınlanan bildirgede de kadınların işgücüne katılımı, kadınlara yönelik ayrımcılıkla ve şiddetle mücadele edilmesi, kadınların kaliteli eğitim imkanlarına kavuşturulması, kadın girişimciliğinin desteklenmesi, ücret farklılıklarının giderilmesi, kadınların dijital imkanlara kavuşturulması, karar verme mekanizmalarında artan temsili gibi konulara odaklanılmıştır (G20 Osaka Leaders' Declaration). 


\section{ULUSLARARASI KURULUŞLARIN, KADINLARIN GÜÇLENDIRILLMESI KO- NUSUNDA KULLANDIĞI SÖYLEM VE KAVRAMLARIN KIYASLANARAK ÖZETLENMESI}

Uluslararası kuruluşların, kadınları ilgilendiren konularla ilgili sözleşmelerdeki ve diğer politika belgelerindeki gündemlerinden, ilgilerinden, yaklaşımların yukarıda bahsedilmiştir. Çalıșmanın bu kısmında uluslararası kuruluşların bu bakış açıları özet olarak bir tabloda ele alınacaktır. Așağıdaki tabloda, Birleșmiș Milletler, ILO, Avrupa Konseyi, Avrupa Birliği, G20 ve İslam İşbirliği Teşkilatı'nın; temel yaklaşımları, kadın konusunu hangi boyuttan ele aldıkları, hangi kavramlar etrafında meseleyi tartıştıkları ve politikalarının odak noktasına neleri yerleștirdikleri analiz edilmektedir.

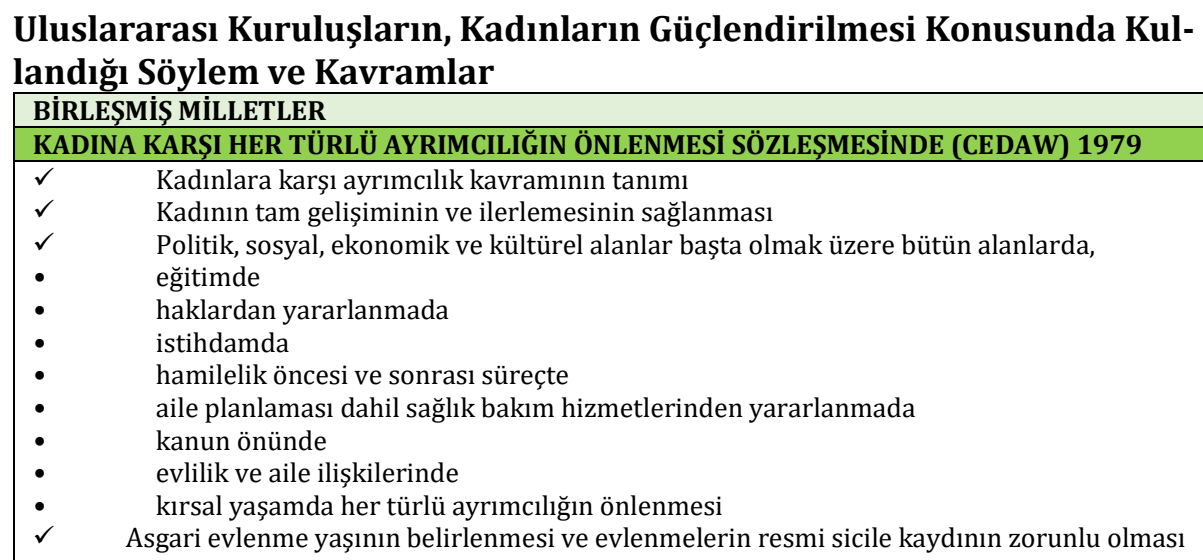

\begin{tabular}{|c|c|}
\hline \multicolumn{2}{|r|}{ KADINA KARŞI ŞİDDETİN ÖNLENMESİNE DAİR BİRLEŞMİŞ MİLLETLER BİLDİRGESİ - 1993} \\
\hline & Kadınlara yönelik şiddet kavramının tanımı \\
\hline$\checkmark$ & Şiddetin içeriğinde yer alan unsurlar \\
\hline$\checkmark$ & Kadın hakları ve özgürlükleri \\
\hline & $\begin{array}{l}\text { Şiddetin önlenmesi, failin cezalandırılması ve şiddete uğrayanın korunması konusunda devlet- } \\
\text { lere düșen hukuksal, eğitimsel ve mali sorumluluklar ve görevlerin düzenlenmesi }\end{array}$ \\
\hline$\checkmark$ & Șiddetin önlenmesinde sivil toplum kuruluşlarıyla işbirlikleri \\
\hline \multicolumn{2}{|r|}{ PEKİN DEKLARASYONU VE EYLEM PLANI - 1995} \\
\hline$\checkmark$ & Kadınların yoksulluğuyla mücadele \\
\hline$\checkmark$ & Kadınlara ve kız çocuklarına her türlü eğitim imkanlarının sağlanması \\
\hline$\checkmark$ & Kadınların sağlık hizmetlerine erișimi \\
\hline$\checkmark$ & Kadına yönelik şiddetle mücadele \\
\hline$\checkmark$ & Kadınların silahlı veya diğer türden çatışmalardan korunması \\
\hline$\checkmark$ & Kadınların ekonomik yapılara ve kaynaklara erişiminin sağlanması \\
\hline$\checkmark$ & Yetki ve karar almanın bütün düzeylerde gerçekleştirilmesi \\
\hline$\checkmark$ & Kadının ilerlemesini sağlayacak bütün düzeylerdeki mekanizmalar oluşturulması \\
\hline$\checkmark$ & Kadının insan haklarına saygı \\
\hline$\checkmark$ & Medyada kadınların katılımı, klişeleşmemiş görüntülerin yaygınlaştırılması \\
\hline$\checkmark$ & Doğal kaynakların yönetiminde ve çevrenin korunmasında kadınların katılımı \\
\hline$\checkmark$ & Kız çocuklarına karşı ayrımcılık yapılmaması ve kız çocuklarının haklarının korunması \\
\hline \multicolumn{2}{|r|}{ BİNYIL (MILENYUM) KALKINMA HEDEFLERI - 2000} \\
\hline$\checkmark$ & Kadın-erkek eşitliğinin sağlanması \\
\hline$\checkmark$ & Kadınların konumunun güçlendirilmesi \\
\hline
\end{tabular}




\begin{tabular}{|c|c|}
\hline$\checkmark$ & $\begin{array}{l}\text { İlköğretim ve orta öğretimde kız-erkek öğrenci eșitsizliğinin her düzeyde giderilmesi } \\
\text { Anne sağlığının iyileștirilmesi }\end{array}$ \\
\hline \multicolumn{2}{|r|}{ KADINLARIN GÜÇLENDİRİLMESİ PRENSİPLERİ- 2010} \\
\hline & İş yaşamında cinsiyet eşitliği için üst düzeyde liderlik ortaya koyulması \\
\hline & $\begin{array}{l}\text { Kadın ve erkek tüm çalışanlara işyerinde adil davranılması, insan hakları ve ayrımcılık yasağı } \\
\text { ilkelerine saygı gösterilmesi ve destek verilmesi }\end{array}$ \\
\hline$\checkmark$ & Kadın ve erkek tüm bireylerin sağlık, güvenlik ve refahlarının sağlanması \\
\hline & Kadınların her türlü eğitim, öğretim ve mesleki gelişim konusunda teşvik edilmesi \\
\hline & $\begin{array}{l}\text { İşyerinde; girişim, iş geliştirme, tedarik zinciri ve pazarlama süreçlerine ilişkin uygulamaların } \\
\text { kadınların güçlenmesine yarayacak șekilde yürütülmesini sağlanması }\end{array}$ \\
\hline & Toplumsal inisiyatifler ve destekler aracılığıyla eşitliğin teşvik edilmesi. \\
\hline & Cinsiyet eşitliğine ilişkin ilerlemenin ölçülmesi ve sonuçlarının kamuoyu ile paylașılması \\
\hline \multicolumn{2}{|r|}{2030 SÜRDÜRÜLEBİLİR KALKINMA AMAÇLARI-2015 } \\
\hline & Cinsiyet eşitliğinin sağlanması \\
\hline & Kadınlara ve kız çocuklarına yönelik her türlü ayrımcılığın her yerde sonlandırılması, \\
\hline$\checkmark$ & şiddetin her türünün yok edilmesi \\
\hline & $\begin{array}{l}\text { Çocuk evliliği, erken yașta ve zorla evlendirilme ile kadın sünneti gibi tüm zararlı uygulamala- } \\
\text { rın yok edilmesi, }\end{array}$ \\
\hline & $\begin{array}{l}\text { Ulusal şartlara uygun şekilde kamu hizmetlerinin, altyapının ve sosyal koruma politikaları- } \\
\text { nın sağlanması ile hanehalkı ve aile içerisinde sorumlulukların paylaşımının teşvik edilmesi } \\
\text { yollarıyla ücretsiz bakım ve ev işlerinin tanınması ve değer atfedilmesi }\end{array}$ \\
\hline & $\begin{array}{l}\text { Kadınların karar alma süreçlerinin her seviyesinde tam ve etkili katılımı ile liderlik edebilme- } \\
\text { leri için eșit fırsatlar sağlanması, }\end{array}$ \\
\hline$\checkmark$ & Cinsel ve üreme sağlığına ve üreme haklarına evrensel erişimin sağlanması, \\
\hline & Kadınların ekonomik kaynaklar konusunda eșit haklara sahip olması için reformlar yapılması \\
\hline & Kadınların güçlendirilmesini destekleyen teknolojilerin, kullanımının artırılması \\
\hline & Kız çocuklarının her seviyede güçlendirilmesi \\
\hline \multicolumn{2}{|r|}{ İSLAM İŞBİRLİĞİ TEŞKİLATI } \\
\hline \multicolumn{2}{|r|}{2025 EYLEM PLANI- 2016} \\
\hline & Kadınların ilerletilmesi ve güçlendirilmesi \\
\hline & Aile refahı ve sosyal güvenlik \\
\hline & Çocuk ve anne sağlı̆̆ \\
\hline & Yaşlıların korunması \\
\hline & Kadınların iyi sağlık koşullarına sahip olması \\
\hline & Kadınların işgücüne katılım oranının artırılması \\
\hline & Kadınların sosyal güvenlik korumasından daha fazla yararlanması \\
\hline & $\begin{array}{l}\text { Ailenin korunması ve desteklenmesi, gençliğin kapasitesinin inşası ve girişimcilik, engellilerin } \\
\text { hakları ve yaşlı bakımı konularında sivil toplumun katılımının güçlendirilmesi }\end{array}$ \\
\hline & Kadınlara ait KOBI'lerin desteklenmesi \\
\hline \multicolumn{2}{|r|}{ İIT EVLİLİĞİN VE AİLENİN GÜÇLENDİRİLMESI STRATEJISİ - 2020} \\
\hline & Kadın ve erkek arasında evliliğin desteklenmesi \\
\hline & Evlilik ve aile temelinde sürdürülebilir kalkınma hedeflerine odaklanılması \\
\hline & Asgari evlilik yaşının belirlenmesi (18 olarak önerilmektedir) \\
\hline & Aile mahkemeleri ve danışmanlık hizmetleri verilmesi \\
\hline & Kadın ve erkek arasında sorumlulukların paylaşıldığı ailenin inşa edilmesi, \\
\hline & $\begin{array}{l}\text { İslami ve genel insani değerler doğrultusunda erkek ve kadınlar arasındaki adalet ve eşitliğin } \\
\text { güçlendirilmesi }\end{array}$ \\
\hline$\checkmark$ & Ailenin Müslüman kimliğinin güçlendirilmesi \\
\hline & İş-aile dengesinin sağlanmasına yönelik aile merkezli ekosistem oluşturulması \\
\hline & $\begin{array}{l}\text { Aile içi şiddetin suç olarak kabul edilmesi, kadına yönelik tüm şiddet türlerinin ortadan kaldı- } \\
\text { rılması }\end{array}$ \\
\hline & $\begin{array}{l}\text { Kadına ve çocuklara yönelik şiddetle mücadele eden yerel ve dini kurumlara finansal ve teknik } \\
\text { destek sağlanması }\end{array}$ \\
\hline & Anaerkil ailelerin desteklenmesi \\
\hline & $\begin{array}{l}\text { Kadınların ve kız çocuklarının eğitim, sağlık, insan onuruna yakışır iş, politik ve ekonomik ka- } \\
\text { rar verme sürecine katılımı için toplumsal cinsiyet eșitliğinin sağlanması }\end{array}$ \\
\hline
\end{tabular}




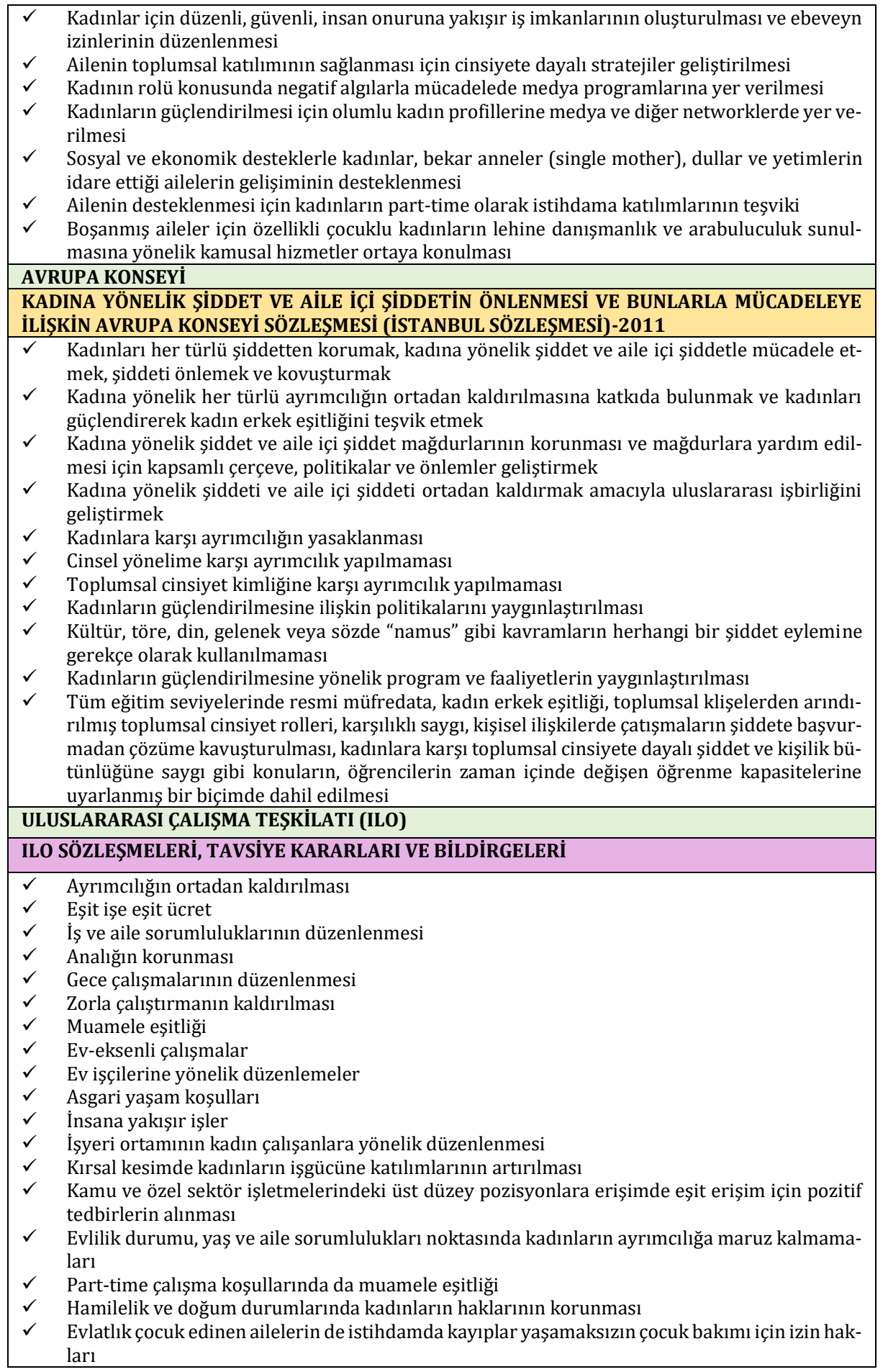




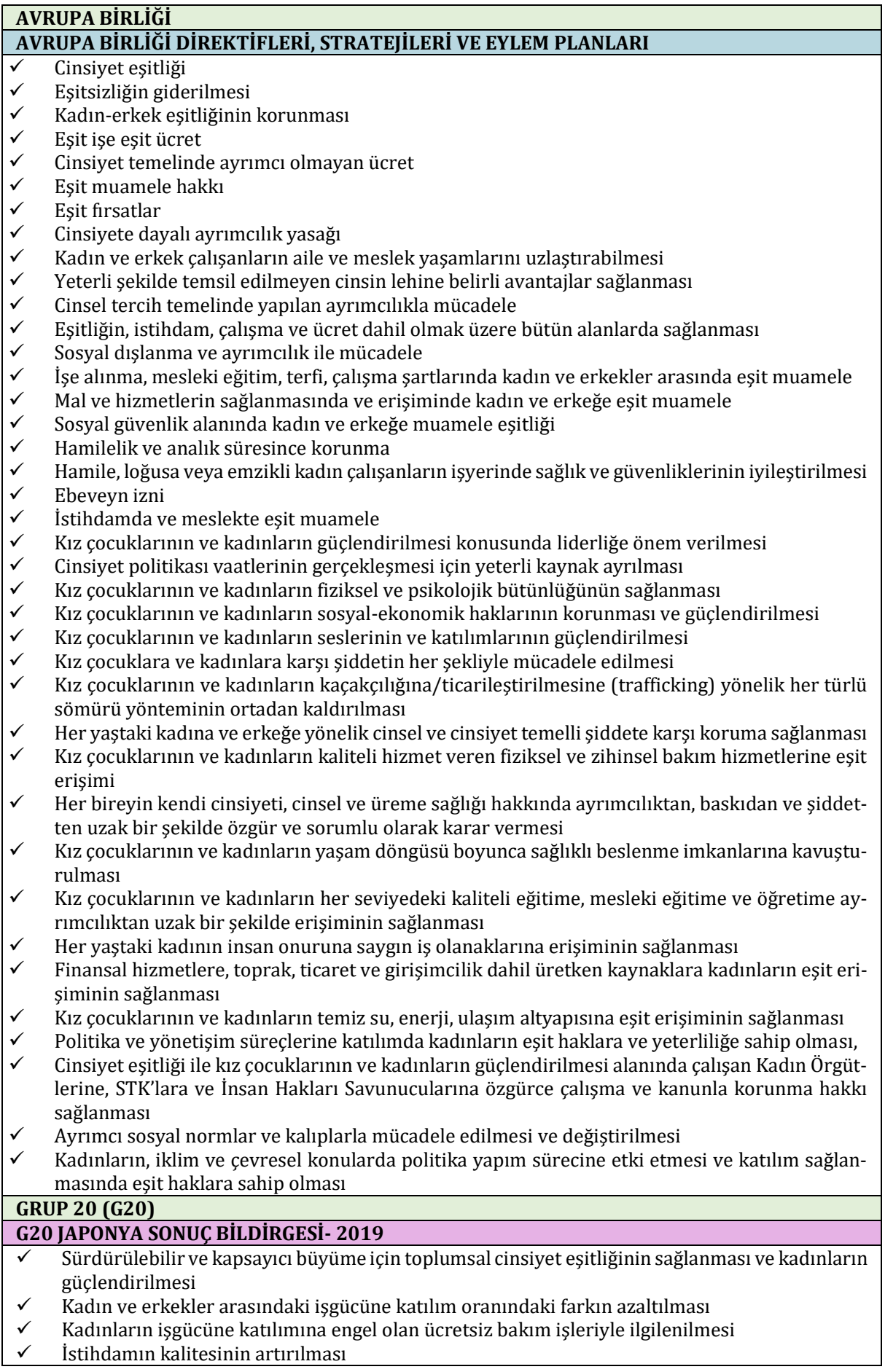




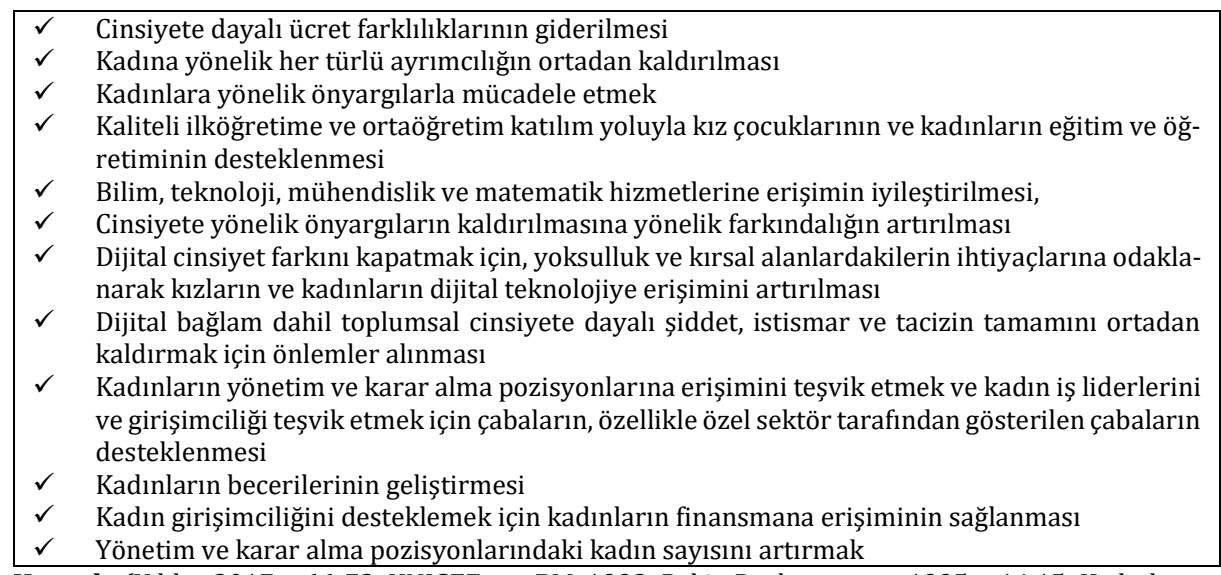

Kaynak: (Yıldız, 2017, s.66-73; UNICEF, t.y; BM, 1993; Pekin Derlarasyonu, 1995, s.14,15; Kadınlara Yönelik Şiddet ve Aile İçi Şiddetin Önlenmesi ve Bunlarla Mücadeleye İlişkin Avrupa Konseyi Sözleşmesi, 2011; G20 Osaka Leaders' Declaration, 2019; OIC Strategy for the Empowerment of the Marriage \& Family Institution 2020-2025 A Guiding Strategy, 2020; THE OIC-2025, 2020.)

Kıyaslamalı olarak uluslararası kuruluşların kadın konusuyla ilgili çalışmaları ele alındığında; insan hakları, ayrımcılık yasağı, kanun önünde eşitlik, eşit işe eşit ücret, muamele eşitliği, eşit fırsatlar, analığın korunması, şiddetle mücadele, anne-çocuk sağlığının korunması başlıkları altında ele alındığı görülmektedir. Süreçle beraber, bu başlıkların çeşitlendiğinin, içeriğinin güçlendirildiğinin ve yeni başlıklar ilave edildiğinin vurgulanması gerekir. Bu bağlamda günümüzde kadın haklarının tescilinin yanı sıra, ağırlıklı olarak, kadınların güçlendirilmesi, kadınlarının sesinin duyurulması, kadına karşı şiddetle mücadele edilmesi, kadınların işgücü piyasasına güçlü bir şekilde katılması, ebeveyn izinleri, evlatlık çocuk edinen ailelerin izin hakları, kadınların politik yaşama katılımı, kadınların finansal varlıklara erişimi, kadın girişimciliğinin desteklenmesi, dijitalleşmeyle cinsiyet eşitliği arasında bağlar kurulması ve hatta cinsel tercih gibi farklı boyutlardan konuların ilave edilerek genişletilerek ele alındığı görülmektedir.

\section{DEĞERLENDİRME VE ÖNERILER}

Kadınların güçlendirilmesi kavramı, uluslararası düzeyde özel bir yer tutmaktadır. Öne çıkan, BM, İiT ILO, AB, AK ve G20 gibi uluslararası kuruluşlar; Antlaşmalar, Sözleşmeler, Bildirgeler, Tavsiye Kararları, Strateji Belgeleri ve Eylem Planları gibi mekanizmalar geliștirerek kadının güçlendirilmesi konusunu ele almakta ve yaklaşımlarını ortaya koyarak sürece etki etmeye çalışmaktadırlar.

Günümüzde uluslararası alanda faaliyet gösteren neredeyse her kurumun artan duyarlılıklar ve kamuoyu beklentileri nedeniyle kadınların güçlendirilmesi konusunu gündemine aldıkları, konuyu içselleştirme yönünde yaklaşımlar geliştirdikleri görülmektedir. Hatta bu alanda politika geliştirmeyen 
ve faaliyet göstermeyen kurumlar eleştiriye uğramaktan kurtulamamaktadır. Her kurum cinsiyet temelli yaklaşımlar ortaya koyarak, formüller geliştirmekte, bazı kavramları odağına yerleştirmektedir.

Bu kapsamda; fitratta farklılık, haklarda eșitlik, pozitif ayrımcllık, cinsiyet ayrımcılığı, şiddete karşı koruyucu ve önleyici tedbirler, erken yaşta evlilikler, töre cinayetleri, anneliğin korunması, aile ve evlilik, ailenin korunması, aile refahı, kadın hak ve özgürlükleri, sosyal koruma, fırsat eşitliği, katılım mekanizmalarına etkin katılım, eşit muamele görme hakkı, kadın girişimciliğin desteklenmesi, kadınların teknolojiyle bulușturulması, eşit işe eşit ücret, kaliteli eğitim, işgücüne katılım şeklinde kavramlar etrafında kadınların güçlendirilmesi konusunun ele alındığı görülmektedir.

Bu kavramlar, kadınların güçlendirilmesi adına yol gösterici kavramlardır. Bu kavramların içselleştirilerek, etrafında projeler üretilmesi, kamu, özel sektör, STK'lar, sendikalar, yerel yönetimler, üniversiteler, medya gibi sosyal tarafların konuyla ilgilenmesi gerekmektedir. Kadınlar da birey olarak sadece beklenti içinde olmadan kendi koşulları, kendi kapasiteleri, kendi bakış açısı çerçevesinde "birey olarak kadın", "aile bireyi olarak kadın", "toplumda kadın" olarak güçlenme konusunda gayret etmelidir. Böyle bir arayış ve gayret politika ve uygulamalara da ayrıca yön verecektir. Bütün sürecin anahtarı, kendisini birey olarak, aile ferdi olarak, inanç olarak, meslek olarak ifade edebilme ve kabul ettirme becerisini ortaya koymaktır.

\section{SONUÇ}

Bu çalışmanın amacı, uluslararası kuruluşların düzenlemelerini bir bütün içinde kadının güçlendirilmesi konusunu inceleyerek, politika geliştirilmesine katkl sağlamaktır.

"Kadınların güçlendirilmesi" kavramı, kadın konusu ile ilgili çalışmalarda, temel kavramlardan biri haline gelmiştir. Kadınların güçlendirilmesi, özellikle, kadınların ekonomik, sosyal, kültürel, siyasal hayatta desteklenmesi, daha görünür hale gelmesi, etkin roller üstlenmesi için kullanılmaktadır.

Birleşmiş Milletler'den Avrupa Birliği'ne, Uluslararası Çalışma Teşkilatından, İslam İşbirliği Teşkilatı'na kadar birçok uluslararası kurum ve kuruluş bu kavramı kullanmaktadır. Bu kapsamda, bu çalışmada, kadınların güçlendirilmesi alanında uluslararası düzenlemeler bağlamında BM, İslam İșbirliği Teşkilatı, ILO, Avrupa Konseyi, AB, G20'nin yaklaşımları incelenerek kıyaslamalı bir değerlendirme yapılmıştır.

Bu bağlamda uluslararası kuruluşların perspektifinden bakıldığında, kadınların güçlendirilmesi, kadınların; fitratının ve onurunun farkına varması, hayatının her döneminde kaliteli eğitim imkanlarına sahip olması; mesleki gelişim olanaklarının desteklenmesi; sağlık, güvenlik, huzur ve refahının sağlanması, iş dünyası- aile hayatı alanında dengenin kurulmasına yönelik tedbirler alınması, ulusal ve uluslararası düzeyde yasal haklarının ve sorumlu- 
luklarının farkına varması, dijital dönüşüm fırsatlarından yararlanması, ekonomik, sosyal, kültürel, siyasal olmak üzere toplumsal alanın herbir noktasında karar alma süreçlerine aktif katılımı için kendini hazırlaması ve hazır hissetmesi konularını içerdiği görülmüștür.

Kadının güçlendirilmesi çerçevesinde; fitrat, onur, liyakat, yetkinlik, işaile dengesinin sağlanması, evliliğin ve ailenin korunması, güvenli, insan onuruna yaraşır iş kavramları önümüzde temel değerler olarak bulunmaktadır. Bu çerçevede kadının güçlendirilmesi, kadının kendisinden beklenen temsil gücünü, etkin ve başarılı bir şekilde hayata geçirmesi anlamına gelmektedir.

Uluslararası kuruluşların neredeyse tamamının kapsamlı çalışmalarına rağmen, hala kadının güçlendirilmesi denince esasında geliştirilmiş bir model bulunmamaktadır.

Bu alanda daha kapsamlı çalışma ve araştırmalara ihtiyaç bulunmaktadır. $\mathrm{Bu}$ anlamda, kadının güçlendirilmesi konusunda daha çok kavram üretmeye, bu kavramlara uygun eylem ve politika geliştirmeye ve etkin uygulama araç ve yöntemlerini geliştirmeye ihtiyaç duyulduğu anlaşılmaktadır.

\section{KAYNAKÇA}

G20. (2019). G20 Osaka Leaders' Declaration, Osaka, Japan, June, 2019 http://www.g20 .utoronto.ca/2019/2019-g20-osaka-leaders-declaration.html adresinden erişilmiştir.

OIC Strategy for the Empowerment of the Marriage \& Family Institution 20202025 A Guiding Strategy, 2020. Erişim: https://www.oic-oci.org/upload/departments/family/oic family strategy 20202025 en.pdf

OIC. (2020). THE OIC -2025 programme of action, https://www.oic-oci.org/docdown/?docID=16\&refID $=5$ adresinden erişilmiştir.

Sürdürülebilir Kalkınma (t.y). Cinsiyet eşitliğini sağlamak. http://www.surdurulebilirkalkinma.gov.tr/hedefler/cinsiyet-esitliginisaglamak adresinden erişilmiştir.

T.B.M.M (1993). Kadınlara yönelik şiddetin ortadan kaldırllmasına dair bildirge. https://www.tbmm.gov.tr adresinden erişilmiștir.

T.B.M.M (2011). Kadınlara yönelik şiddet ve aile içi şiddetin önlenmesi ve bunlarla mücadeleye ilişkin avrupa konseyi sözleşmesi, https://www.tbmm.gov.tr/sirasayi/donem24/yil01/ss81.pdf adresinden erişilmiştir.

T.B.M.M. (1995). Pekin deklarasyonu ve eylem planı: Dördüncü kadın dünya konferansı sonuçları. 14,15, https://kadininstatusu.aile.gov.tr adresinden erişilmiştir.

UN. (2015). The millennium development goals report 2015. http://www.un.org/millenniumgoals/2015_MDG_Report/pdf/MDG\%202015\%20rev\%20(July\%201).pdf adresinden erişilmiştir. 
UNDP. (2010). Binyıl kalkınma hedefleri. https://www.tr.undp.org/content/turkey/tr/home/mdgoverview/millennium-development-goals.html adresinden erişilmiştir.

UNICEF. (2004). Kadınlara karşı her türlü ayrımcılığın önlenmesi uluslararası sözleşmesi, https:// www. unicef.org/turkey/cedaw/_ adresinden erişilmiştir.

Women's Empowerment Principles. (t.y). Home. http://www.weprinciples.org/ adresinden erişilmiştir.

Women's Empowerment Principles. (t.y). WEPS signatories https://www.weps.org/companies adresinden erişilmiștir.

Yıldız, N. (2017), Cinsiyet eşitliği alanında uluslararası referanslar. Eğitim Modülü Cinsiyet Eşitliği: Fıtratta Farklılık: Haklarda Eşitlik Eşit Fırsatlar Eşit Davranma, Eşit Katkl, içinde (s.19-78). Ankara: HAK-İș Konfederasyonu Yayınları, Uçan Matbaacılık, 